\title{
Residential Satisfaction in Different Urban Structures
}

\section{Spokojenost obyvatel v různých urbanistických strukturách}

Jana Matyášová

Ústav urbanismu, Fakulta architektury, Vysoké učení technické v Brně

školitel: doc. Ing. arch. Gabriel Kopáčik, Dr.

\begin{abstract}
This study compares the results of a questionnaire survey focused on residential satisfaction. The survey was a part of the GA17-26104S project and was undertaken in five different residential areas in Brno. These residential areas were selected to represent different types of urban structures. The evaluation of the results of the questionnaire survey could thus contribute to explaining the relationship between urban structure and residential satisfaction.
\end{abstract}

KEYWORDS: urbanism; Brno; residential satisfaction; urban structure

\begin{abstract}
ABSTRAKT: Tento článek porovnává výsledky dotazníkového šetření zaměřeného na spokojenost obyvatel, které v rámci projektu GA17-26104S: Vliv charakteru a umístění urbanistické struktury na udržitelný rozvoj území proběhlo v pěti brněnských obytných souborech. Obytné soubory, ve kterých průzkum probíhal, byly vybrány tak, aby zastupovaly odlišné typy urbanistických struktur. Vyhodnocení dotazníkového šetření by tak mohlo přispět k vysvětlení vztahu mezi urbanistickou strukturou a spokojeností obyvatel.
\end{abstract}

KLÍČOVÁ SLOVA: urbanismus; Brno; spokojenost obyvatel; urbanistická struktura 


\section{Úvod}

Spokojenost obyvatel nebo kvalita života ve městech jsou předmětem mnoha světových studií, některé z nich jsou čistě vědecké (Urban Audit Perception Survey, 2004), avšak existuje i řada spíše populárních žebříčků nejoblíbenějších evropských měst apod. I město Brno má něco jako hodnocení kvality života v městě Brně pomocí aplikace, do které sami obyvatelé vepisují, která místa se jim líbí a která nelíbí a proč (Mapa kvality života, 2018). Zmíněné průzkumy obecně hodnotí celkovou kvalitu života obyvatel v konkrétních městech.

Tento článek se zabývá spokojeností obyvatel v různých urbanistických strukturách ve městě Brně. Spokojenost obyvatel je zde chápána jako spokojenost rezidentů konkrétního bytového nebo rodinného domu či jejich uskupení nebo v širším smyslu jako spokojenost obyvatel s jejich bydlením, bydlištěm a s jeho okolím.

Spokojenost obyvatel je v současné literatuře determinována celou řadou faktorů, které ji mohou ovlivňovat; jedná se o umístění bytové jednotky ve vztahu ke službám v okolí či k lokálnímu centru, hygienické požadavky na byt (prašnost, blízkost zdroje hluku, výhled či osvětlení bytu), sociologické faktory (vztahy se sousedy, soudržnost komunity) a další. Urbanistická struktura je vnímána jako další možný determinant či soubor dílčích determinantů, které spokojenost obyvatel ovlivňují.

Nás zajímá především urbanistická struktura a to, jaký je vztah mezi urbanistickou strukturou a spokojeností obyvatel. Lze urbanistickou strukturu chápat jako jeden z determinantů či hlavní determinant spokojenosti obyvatel, nebo je spokojenost obyvatel tak komplexní a ovlivněná tolika faktory, že různorodost urbanistické struktury při hodnocení spokojenosti obyvatel nehraje podstatnou roli?

\section{Studie spokojenosti obyvatel}

Kvalita života v obytných souborech a spokojenost jejich obyvatel jsou tématem mnoha studií prováděných po celém světě. Ve zkratce je zde uveden pouze jejich malý výčet.

PodleMohita(Mohit,2012)existujívzásadědvatypystudiíspokojenostiobyvatel;jednak ty, které považují spokojenost obyvatel za ukazatel chování (úmysl zůstat/přestěhovat se z existujícího bydlení), jednak ty, v nichž je spokojenost obyvatel chápána jako kritérium kvality bydlení (Weidemann, 1985). Základem prvního předpokladu je, že rozdíly mezi stávajícím bydlením a skutečnými potřebami ve vztahu k bydlení a preferencemi obyvatel budou mít za následek bud' změnu stávajícího bydlení, nebo 
přemístění do bytové jednotky, která odpovídá jejich skutečným preferencím a potřebám v oblasti bydlení (Mohit, 2012). Studie, které chápou spokojenost obyvatel jako měřítko kvality bydlení, určují, do jaké míry je osoba spokojena se stávající bytovou jednotkou (Amerigo, 1990).

Nizozemská studie zkoumající spokojenost obyvatel žijících blízko dálnice (Hamersma, 2014) ukazuje, že spokojenost obyvatel se pravděpodobně zvyšuje s vyššími příjmy, vyšším vzděláním a vyšším věkem. První dva faktory souvisí s lepší možností vybrat si místo, kde chce rezident bydlet, třetí faktor souvisí s delším vztahem k místu.

Ve studii provedené v českých, slovenských a rakouských městech v letech 2015-2017 byl definován index spokojenosti obyvatel. (Wittmann a kol., 2017) Je to procentuální podíl součtu konkrétních bodů za odpovědi získané dotazníkovým šetřením. Je tedy podle Wittmanna výrazem míry spokojenosti obyvatel - čím vyšší hodnocení, tím vyšší spokojenost. Z této studie vychází také metodika hodnocení použitá v tomto článku, avšak pro přesnější použití indexu spokojenosti obyvatel při vyhodnocování byla nutná malá úprava ve vztahu k odlišnostem použitých dotazníků.

\section{Metodika}

Specifické skupiny lidí mohou hodnotit obdobné podmínky bydlení odlišným způsobem vzhledem ke svým konkrétním potřebám a preferencím týkajícím se bydlení a okolí domu. Příčinou odlišných výsledků může být také použití nevhodných statistických metod. (Mridha, 2015) Nejčastější metodou zkoumání spokojenosti obyvatel je šetření pomocí dotazníku (např. Hamersma, 2014; Mohit, 2012). Dotazníky se však liší obsahem či formou.

Pro hodnocení spokojenosti obyvatel neexistuje univerzální návod či metodika aplikovatelná celosvětově, nebot faktory vstupující do hodnocení spokojenosti obyvatel souvisejí mimo jiné s danou lokalitou. Každá současná studie si hledá cestu, jak v daných konkrétních podmínkách nejlépe uchopit a definovat spokojenost obyvatel v dané lokalitě. Tato studie se zabývá pouze pěti obytnými soubory ve městě Brně, přičemž z výsledků lze vyvodit ve vztahu k obecnějším tvrzením pouze orientační závěry.

Dalším krokem výzkumu by mohla být snaha o vyvinutí nějaké ucelené a jednotné metodiky či formulaci jednotlivých doporučení pro zvýšení spokojenosti obyvatel, které by byly aplikovatelné na česká města a české prostředí. Ve vztahu k západním evropským státům lze tvrdit, že v České republice nebylo provedeno zatím takové množství studií spokojenosti obyvatel, ze kterého by se tato metodika dala vytvořit. Pro tyto menší studie se zdá být vhodné použití metodiky, která byla již v nějaké jiné studii ověřena a pomohla vyvodit relevantní výsledky. 
Pro zkoumání spokojenosti obyvatel v Brně byla vybrána metodika, která byla použita v projektu GA15-05237S. V tomto projektu byl hodnocen sociologický pilíř udržitelného rozvoje volných prostor mezi obytnými budovami pomocí dotazníkového šetření, které bylo vztaženo na podmínky středoevropské společnosti a možné lokální determinanty spokojenosti obyvatel, proto se pro šetření obytných souborů v Brně jeví jako nejvhodnější ( $\mathrm{z}$ důvodu podobnosti možných determinantů spokojenosti obyvatel).

Dotazník je zaměřen na otázky společenské, jako jsou sousedské vztahy či zapojení do komunity obytného souboru, včetně otázek týkajících se veřejného vybavení v okolí bydliště a dopravní dostupnosti centra či práce, a otázky hygienické, jako je vnímání prašnosti, větrnosti, hluku. Do těchto dvou skupin otázek jsou také rozděleny výsledky získané prostřednictvím dotazníku. V dotazníku jsou kladeny také otázky, odpovědi na něž lze vyčíst ze statistických dat pro město Brno (průměrný plat, vzdělání, věk) a které mohou pomoci pochopit, která část obyvatel byla ochotná na dotazník odpovídat.

Každá otázka v dotazníku je obodována na škále $0-5$ bodů či $0-10$ bodů podle důležitosti odpovědi, pravděpodobné nejčastější odpovědi a podle vypovídací hodnoty otázky tak, aby byly body relevantní a vzájemně porovnatelné. Bodové hodnocení vychází z metodiky použité ve výzkumu v knize Mezi domy, mezi lidmi? (Wittmann a kol., 2017). Při vyhodnocování lze body chápat jako ukazatele spokojenosti obyvatel, tedy čím více bodů, tím byl obytný soubor hodnocen lépe.

Dotazník byl připraven v rámci projektu GA17-26104S: Vliv charakteru a umístění urbanistické struktury na udržitelný rozvoj území. Byl dostupný v papírové podobě, vhazoval se obyvatelům do schránek. Obyvatelé obytných souborů však měli také možnost vyplnit dotazník v elektronické podobě, což v některých obytných souborech značně zvýšilo účast respondentů. Šetření probíhalo v každém obytném souboru během deseti až čtrnácti dnů, přičemž byly dotazníky průběžně sbírány, aby nedocházelo k jejich ztrátě. Celkem bylo shromážděno 283 vyplněných dotazníků z 1480 připravených, což se považuje za relevantní vzorek. Srovnávaná data jsou z obytných souborů v pěti městských částech:

Lokalita č. 1: Brno-střed - lokalita je tvořena historickou zástavbou centra města, nachází se mezi ulicemi Joštova, Husova, Benešova a Koliště, zahrnuje tedy celé vnitřní centrum města. Jedná se zpravidla o vícepodlažní zástavbu polyfunkčních historických budov, obytná funkce je převážně ve vyšších podlažích ředěna administrativní funkcí a v parteru obchody a restauracemi, kavárnami či hospodami. Budovy jsou uspořádány do historicky vzniklých bloků s malými vnitrobloky, které jsou často zastavěny drobnými stavbami. 
Lokalita č. 2: Pisárky - lokalita je tvořena zástavbou převážně samostatně stojících rodinných domů a vil, která je doplněna několika domy v řadové zástavbě a pár bytovými domy. Jedná se o území mezi Wilsonovým lesem, ulicí Hlinky, Vaňkovým náměstím a náměstím Míru a ulicí Údolní. Jedná se o velmi luxusní vilovou čtvrt', která má historickou hodnotu (vily z konce 19. a ze začátku 20. století včetně let 30.) a má velmi blízko snadno dostupné centrum města. Je obklopena velkým parkem na Kraví hoře a lesem vhodným na kratší procházky přírodou.

Lokalita č. 3: Veveří - lokalita se nachází v blízkosti městského centra, v oblasti nazývané Veveří, v okolí ulic Botanická, Dřevařská, Hrnčířská až po ulici Štefánikovu. Jedná se o zástavbu bytových domů převážně z přelomu 19. a 20. století, které jsou uspořádány do městských bloků. Tyto bytové domy mají vstupy orientované do ulic a vytváří pravidelné struktury domů s polosoukromými vnitrobloky. Ve vnitrobloku, kam se zpravidla dostanou jen rezidenti, se může nacházet zeleň či různá hřiště, případně zahrádky restaurací umístěných ve vnitrobloku.

Lokalita č. 4: Královo Pole - z lokality je přímo dostupné centrum města, jedná se o část městské části Královo Pole mezi ulicemi Palackého třída, Skácelova, Purkyňova a Červinkova. Lokalita je tvořena převážně řadovou rodinnou zástavbou, kde je i několik bytových domů. Urbanistická struktura lokality je pravidelná, domy jsou opět seskupeny do bloků, přičemž zde jsou vnitrobloky rozparcelované a každý rodinný dům má svoji soukromou zahradu ve vnitrobloku. Rodinné domy mají často drobné předzahrádky orientované do ulic.

Lokalita č. 5: Bystrc - ze zkoumaných lokalit je tato lokalita nejvzdálenější od městského centra, avšak s přímou tramvajovou linkou přímo do centra. Jedná se o Bystrc II, tedy panelové sídliště s volnou zástavbou v městské části Brno-Bystrc, jižně od tramvajové smyčky na ulici Ečerova. Jsou zde 8- až 12podlažní panelové domy z 2. poloviny 20. století. Jedná se bud’ o bodové panelové domy, či panelové domy v řadové zástavbě. Domy jsou obklopené veřejnou parkovou zelení (tráva, keře, několik stromů).

\section{Výsledky}

V následujících tabulkách jsou vypsány výsledky dotazníkového šetření, v první tabulce $\mathrm{z}$ oblasti hygieny, $\mathrm{v}$ druhé tabulce $\mathrm{z}$ oblasti společenské. Otázky mají podle zvolené metodiky názvy dle názvů indikátorů v pilírích udržitelnosti a přiřazené body byly spočítány jako průměrná hodnota ze všech dotazníků vyhodnocených pro danou lokalitu. 
ČÁST 1 - HYGIENA

LOKALITA 1 LOKALITA 2 LOKALITA 3 LOKALITA 4 LOKALITA 5

\begin{tabular}{|l|c|c|c|c|c|}
\hline přjemné prosvětlení bytu & 6,66 & 9,28 & 7,05 & 8,48 & 8,19 \\
\hline nedostatečné osvětlení bytu & 3,7 & 7,42 & 7,5 & 9,37 & 8,25 \\
\hline přehřívání bytu & 3,35 & 3,42 & 3,08 & 3,1 & 2,27 \\
\hline vnímání větrnosti obyvateli & 3,95 & 4,08 & 4,26 & 4,3 & 3,05 \\
\hline subjektivní vnímání prašnosti & 2,7 & 4,27 & 3,4 & 3,52 & 3,55 \\
\hline obtěžování hlukem z dopravy & 4,33 & 4,59 & 4,13 & 3,95 & 3,86 \\
\hline $\begin{array}{l}\text { obtěžování hlukem ze } \\
\text { společenských venkovních } \\
\text { aktivit }\end{array}$ & 2,79 & 4,56 & 3,44 & 3,91 & 3,91 \\
\hline obtěžující hluk z okolních bytů & 4,04 & 4,53 & 3,8 & 4,58 & 3,75 \\
\hline obtěžování místními pachy & 2,83 & 4,93 & 3,97 & 4,14 & 3,94 \\
\hline nežádoucí hmyz & 4,58 & 4,55 & 4,33 & 4,58 & 3,88 \\
\hline nežádoucí hlodavci & 4,25 & 4,77 & 4,31 & 4,56 & 4,32 \\
\hline
\end{tabular}

ČÁST 2 - SPOLEČNOST

\begin{tabular}{|c|c|c|c|c|c|}
\hline subjektivní zdravotní stav & 8,1 & 7,29 & 7,25 & 7,29 & 7,21 \\
\hline střední měsíční přijem & 5 & 5 & 7,5 & 5 & 5 \\
\hline $\begin{array}{l}\text { pocit nebezpečí v lokalitě ve } \\
\text { dne }\end{array}$ & 4,54 & 4,86 & 4,51 & 4,91 & 4,63 \\
\hline $\begin{array}{l}\text { pocit nebezpečí v lokalitě v } \\
\text { noci }\end{array}$ & 3,08 & 4,33 & 3,68 & 4,45 & 4,15 \\
\hline nedůvěryhodné cizí osoby & 2,56 & 4,36 & 3,15 & 4,26 & 3,76 \\
\hline dobrá adresa & 8,1 & 8,36 & 7,94 & 8,8 & 7,63 \\
\hline $\begin{array}{l}\text { dostupnost občanského } \\
\text { vybavení }\end{array}$ & 6,98 & 4,62 & 6,05 & 6,48 & 6,38 \\
\hline $\begin{array}{l}\text { rozmanitost využití okolí } \\
\text { domu }\end{array}$ & 5,43 & 5,11 & 5,23 & 7,6 & 5,95 \\
\hline přizpůsobení imobilním & 5,02 & 5,38 & 4,25 & 7,88 & 6,46 \\
\hline pocit domova & 6,77 & 8,82 & 7,5 & 8,28 & 7,44 \\
\hline př́jemný výhled & 5,1 & 8,97 & 5,11 & 6,14 & 5,97 \\
\hline pocit omezení soukromí & 3,04 & 4,04 & 3,22 & 3,59 & 3,56 \\
\hline vnímání estetické kvality & 7,33 & 8,85 & 6,75 & 8,31 & 7,48 \\
\hline stěhování - změna sousedů & 3,9 & 8,06 & 4,22 & 7,44 & 6,97 \\
\hline starousedlictví & 8,54 & 9,42 & 7,88 & 8,72 & 9,83 \\
\hline sousedské vztahy & 7,39 & 7,75 & 7 & 7,86 & 7,11 \\
\hline $\begin{array}{l}\text { spoluúčast na údržbě } \\
\text { prostorů kolem bydliště }\end{array}$ & 4,01 & 4,94 & 4 & 4,89 & 4,16 \\
\hline
\end{tabular}

V následující tabulce jsou patrné celkové součty v jednotlivých oblastech pro každou lokalitu.

LOKALITA 1 LOKALITA 2 LOKALITA 3 LOKALITA 4 LOKALITA 5

$\begin{array}{cccccc}\text { ČÁST 1 - HYGIENA } & 43,18 & 56,40 & 49,27 & 54,49 & 48,97 \\ \text { ČÁST 2 - SPOLEČNOST } & 94,89 & 110,16 & 95,24 & 111,9 & 103,69 \\ \text { CELKEM } & 138,07 & 166,56 & 144,51 & 166,39 & 152,66\end{array}$

Rozdílnost urbanistických struktur u těchto pěti vybraných lokalit by mohla v hodnocení respondentů hrát roli. Nejpozitivnější hodnocení poskytli respondenti z lokalit, kde je bud’ samostatně stojící rodinná zástavba, či řadová rodinná zástavba velmi blízko centru města. Obě tyto lokality také charakterizuje dostatek prostoru, soukromí a blízkost všech služeb. Další lokalitou je sídliště, v němž, ačkoliv je po- 
měrně daleko od centra města, respondenti hodnotili dostupnost poměrně dobře. Bytové domy tvořící městské bloky byly hodnoceny o něco hůře. Zde si respondenti velmi stěžovali na málo parkovacích míst a málo zeleně. Urbanistickou strukturou na posledním místě je historické jádro, kde respondenti zmiňovali problémy s hlukem, s parkováním a š̌astou výměnou sousedů.

\section{Závěr}

Vyhodnocení dotazníkového šetření potvrdilo domněnku, že spokojenost obyvatel je ovlivněna urbanistickou strukturou. Jak podstatným determinantem spokojenosti obyvatel urbanistická struktura je, tedy konkrétnější definici vztahu mezi urbanistickou strukturou a spokojeností obyvatel, je nutné ověřit další, podrobnější studií obsahující více obytných souborů.

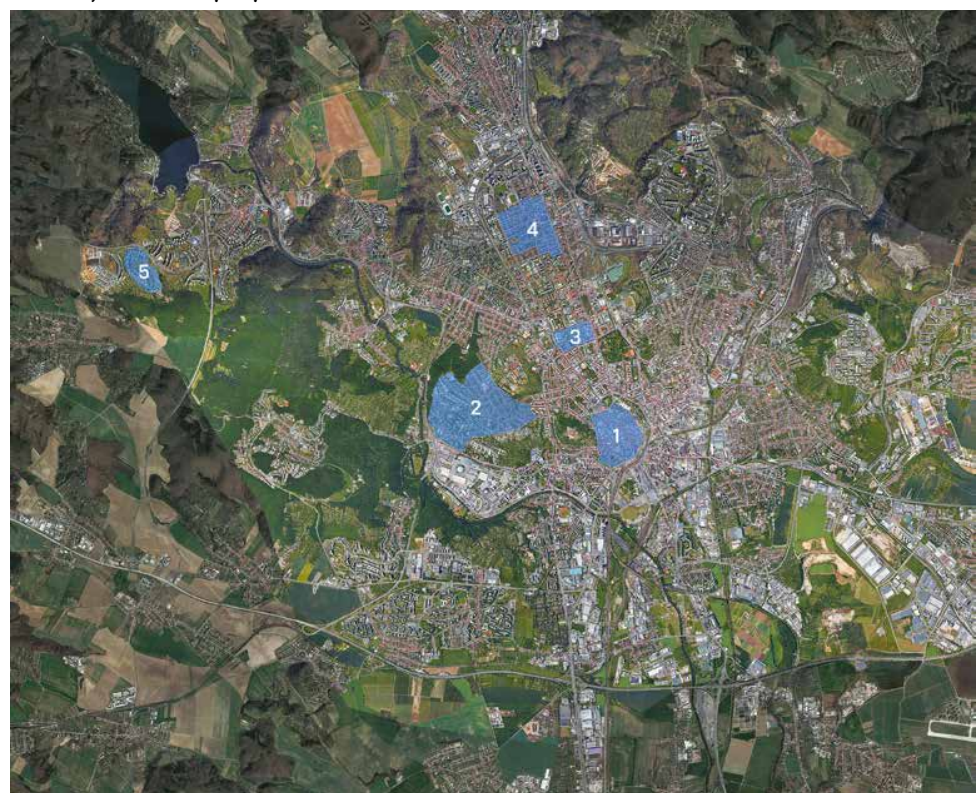

Obr. 1. Situace Brno - lokality (Zdroj: archiv autora)

\section{Použitá literatura}

AMERIGO, M. a J.I. ARAGONES, 1997. A theoretical and methodological approach to the study of residential satisfaction, Journal of Environmental Psychology, 17, 47-57. CAMPBELL, A., P. CONVERSE a W. RODGERS, 1976. The Quality of American Life: Perceptions, Evaluations and Satisfactions, Russell Sage Foundation, New York CAO, X. (J.), 2016. How does neighborhood design affect life satisfaction? Evidence 
from Twin Cities. Travel Behaviour and Society. Elsevier, 5, 68-76 [cit. 2018-0804]. DOI: 10.1016/j.tbs.2015.07.001. ISSN 2214-367X

CRESWELL J.W., 2013. Research design Qualitative quantitative and mixed methods approaches, DOI: 10.1007/s13398-014-0173-7.2

FORNARA, F., M. Bonaiuto, a M. Bonnes, 2010. Cross-validation of abbreviated perceived residential environment quality (PREQ) and neighborhood attachment (NA) indicators. Environment and Behavior, 42(2), 171-196.

GA17-26104S, Vliv charakteru a umístění urbanistické struktury na udržitelný rozvoj území, zahájení: 01.01.2017, ukončení: 31.12.2019

GA15-05237S, Význam volných prostorů pro udržitelný urbánní rozvoj, zahájení: 01.01.2015, ukončení: 31.12.2017

GALSTER G.C. a G.W. HESSER, 1981. Residential satisfaction: Compositional and contextual correlates Environment and Behavior, 13 (6) (1981), pp. 735-758

HANÁK, Tomáš; MAROVIĆ, Ivan; AIGEL, Petr. Perception of residential environment in cities: a comparative study. Procedia Engineering, 2015, 117: 495-501.

HAMERSMA, M., T. TILLEMA, J. SUSSMAN a J.ARTS, 2014. Residential satisfaction close to highways: The impact of accessibility, nuisances and highway adjustment projects. Transportation Research Part A [online]. Elsevier, 59(C), 106-121 [cit. 2018-06-08]. DOI: 10.1016/j.tra.2013.11.004. ISSN 0965-8564.

HUR, M. a H. MORROW JONES, 2008. Factors that influence residents' satisfaction with neighborhoods. Environment and Behavior, 40, pp. 619-635

KROESEN, M., E. MOLIN, H. VOS, S. JANSSEN a B. VAN WEE, 2010. Estimation of effects of transportation noise annoyance on residential satisfaction. Transportation Research D, 15 , pp. 144-153

LU M., 1999. Determinants of residential satisfaction: ordered logit vs regression models. Growth and Change, 30, pp. 264-287

MAPA KVALITY ŽIVOTA, 2018, dostupné z: https://data.brno.cz/aplikace-a-analyzy/ [cit. 2018-08-23]

MOHIT, M. A.l a M. AZIM, 2012. Assessment of Residential Satisfaction with Public Housing in Hulhumale', Maldives. Procedia - Social and Behavioral Sciences. Elsevier, 2012, 50(C), 756-770 [cit. 2018-08-01]. DOI: 10.1016/j.sbspro.2012.08.078. ISSN 1877-0428.

MRIDHA, Mozammel. Living in an apartment. Journal of Environmental Psychology, 2015, 43: 42-54.

RIAZI, M. a A. EMAMI, 2018. Residential satisfaction in affordable housing: A mixed method study. Cities. Elsevier, 2018 [cit. 2018-07-02]. DOI: 10.1016/j.cities.2018.04.013. ISSN 0264-2751.

Urban Audit Perception Survey (2004) - Local Perceptions of Quality of Life in 31 European Cities. Dostupné z: http://www.urbanaudit.org/

WEIDEMANN, S. a J.R. ANDERSON, 1985. A conceptual framework for residential satisfaction. In Altman, I \& Werner, C. H., (Eds.), Home environments. NY: Plenum Press.

WITTMANN, Maxmilian, ed., 2017. Mezi domy, mezi lidmi?: Význam volných prostorů pro udržitelný urbánní rozvoj. 1. Brno: Cerm. ISBN 978-80-7204-955-4. 